\title{
Effect of soil type and vermicompost applications on tomato growth
}

\author{
Marc A. Zucco ${ }^{1}$ S. Alan Walters ${ }^{2} \cdot$ She-Kong Chong ${ }^{2} \cdot$ Brian P. Klubek $^{2}$ • \\ Joseph G. Masabni ${ }^{3} \mathbb{B}$
}

Received: 25 March 2014/Accepted: 8 April 2015/Published online: 18 April 2015

(c) The Author(s) 2015. This article is published with open access at Springerlink.com

\begin{abstract}
Background Vermicomposts (VC) improve plant growth and development beyond that normally observed from just soil nutrient transformation and availability. These increases in plant productivity have been attributed to improved soil structure and soil microbial populations that have higher levels of activity and greater production of biological metabolites, such as plant growth regulators. Although there have been many studies on the benefits of $\mathrm{VC}$ as a fertilizer source, little research has focused on the effects and/or interactions of soil type and VC application rates on vegetable crop productivity. This paper identifies optimum application rate(s) of $\mathrm{VC}$ on tomato growth responses for three different textural classes of soils (loamy sand, silt loam, and silty clay).
\end{abstract}

Joseph G. Masabni

jmasabni@ag.tamu.edu

Marc A. Zucco

m_zucco@yahoo.com

S. Alan Walters

awalters@siu.edu

She-Kong Chong

skchong@siu.edu

Brian P. Klubek

bklubek@siu.edu

1 USDA, Natural Resources Conservation Service, Grayling, MI 49738, USA

2 Department of Plant, Soil, and Agricultural Systems, Southern Illinois University, MC 4415, 1205 Lincoln Dr., Carbondale, IL 62901, USA

3 Department of Horticultural Sciences, Texas A\&M University, 2134 TAMU, College Station, TX 77843-2134, USA
Results Soils with high VC rates $(0.4$ and $0.8 \mathrm{~g} / \mathrm{g})$ produced taller plants with more leaf and flower numbers, higher leaf chlorophyll content, greater plant biomass, and more total leaf area compared to soils with low $\mathrm{VC}$ rates $(0.05,0.1$, and $0.2 \mathrm{~g} / \mathrm{g})$. Tomato growth increases were also observed at the low VC soil amendment rates compared to the nontreated control. Tomatoes grown in the sandy soil amended with VC generally had the greatest growth responses (plant height, leaf and flower number, and leaf chlorophyll content) compared to the clay or silt loam soils, with the silt loam soil generally providing the least response.

Conclusions This research indicated that VC is a suitable alternative fertilizer for tomato, with approximately $0.5-0.6 \mathrm{~g} / \mathrm{g}$ VC added to soil resulting in optimal tomato plant growth. Moreover, this rate provided tomato growth results similar to the standard inorganic fertility program. The sandy soil with VC amendments generally increased tomato plant growth parameters the most compared to the clay and loam soils, with the loam soil generally providing the least.

Keywords Earthworms - Organic wastes - Recycling · Solanum lycopersicon

\section{Introduction}

Vermicomposts (VC) are finely divided, peat-like materials with high porosity, aeration, drainage, water-holding capacity, and microbial activity (Edwards 2004; Pandya et al. 2014). These composts result from a non-thermophilic biodegradation and stabilization of organic materials through interactions of earthworms and microorganisms (Edwards 2004; Arancon et al. 2003; Agnieszka et al. 
2013). A wide range of organic residues, including sewage sludge, animal wastes, crop residues, and industrial refuse are increasingly being converted by earthworms to form VC (Edwards 2004; Roberts et al. 2007; Pascal et al. 2010). The earthworms breakdown the organic residues, which stimulate greater microbial activity, increase nutrient mineralization rates, and rapidly convert the wastes into a humus-like substance that has a finer structure than ordinary composts while possessing greater and more diverse microbial populations (Atiyeh et al. 2000; Yadav and Garg 2011).

Various types of composts, including VC, are often used in sustainable farming systems to improve soil physical properties, provide plant nutrients, and recycle organic wastes. Vermicomposts have been shown to increase plant growth and crop yields in managed and natural ecosystems (Edwards 2004; Arancon et al. 2003; Gutiérrez-Miceli et al. 2007; Pascal et al. 2010). Organic wastes converted to VC have beneficial effects on plant growth and development that are unrelated to increases observed only from soil nutrient transformation and availability. Vermicomposts improve seed germination, seedling vigor, and plant productivity more than what would have been possible from inorganic mineral nutrient sources, while using as little as $10-40 \%$ of the total plant rooting volume (Subler et al. 1998; Gopalakrishnan et al. 2012; Alsina et al. 2013). These increases in plant productivity have been attributed to improved soil structure and soil microbial populations with higher levels of activity and greater production of biological metabolites, such as plant growth regulators (Pascual et al. 1997; Canellas et al. 2002; Atiyeh et al. 2002; Roberts et al. 2007).

Although there have been many studies relating to the benefits of using VC as a fertilizer source (Arancon et al. 2003, 2004a, b; Alsina et al. 2013), little research has focused on the effects and/or interactions of soil type and VC applications on vegetable crop productivity. Therefore, the objective of this research was to identify the optimum application rate(s) of $\mathrm{VC}$ on tomato growth responses for three different textural classes of soils (loamy sand, silt loam, and silty clay).

\section{Methods}

A study was conducted at the Southern Illinois University Horticulture Research Center Greenhouse in Carbondale, Illinois, USA to determine the effects and/or interactions of soil type and VC applications on tomato growth. The experiment was a $3 \times 7$ factorial in a randomized complete block design with four replications and was repeated twice in the greenhouse. Three different textural classes of soils (sandy, loamy, and clayey) were amended with seven VC treatments: (1) untreated control (0 g/g VC), (2) standard fertilizer treatment (SFT) with $0 \mathrm{~g} / \mathrm{g} \mathrm{VC}$ and $2 \mathrm{~g}$ per pot of an inorganic 12-12-12 fertilizer [N-P-K; nitrogen, phosphorus from $\mathrm{P}_{2} \mathrm{O}_{5}$, potassium from $\mathrm{K}_{2} \mathrm{O}$; ; (3) $0.05 \mathrm{~g} / \mathrm{g} \mathrm{VC}$; (4) $0.1 \mathrm{~g} / \mathrm{g} \mathrm{VC}$; (5) $0.2 \mathrm{~g} / \mathrm{g} \mathrm{VC}$; (6) $0.4 \mathrm{~g} / \mathrm{g} \mathrm{VC}$; and (7) $0.8 \mathrm{~g} / \mathrm{g}$ VC. The VC was obtained from New Horizon Organics (Jerseyville, IL, USA). The sandy soil came from an inclusion of sandy orthents within a Medway silty clay loam (Fine-loamy, mixed, mesic Fluvaquentic Hapludolls) in Union county, Illinois, USA (Miles 1979; Fehrenbacher et al. 1984). The other soils were collected in Jackson county, Illinois, USA with the loamy soil collected from a Hosmer silt loam (Fine-silty, mixed, mesic Typic, Fragiudalf) and the clayey soil collected from a Darwin silty clay (Fine, smectitic, mesic Vertic Haplaquolls) (Herman 1979; Fehrenbacher et al. 1984). All soil samples were collected (surface to $15 \mathrm{~cm}$ depths) from fields historically used to produce corn (Zea mays) and soybean (Glycine max). Particle size distribution of each soil was analyzed by the hydrometer method to confirm soil textural class (Table 1; Sabey et al. 2003). All soils were steam pasteurized at approximately $70{ }^{\circ} \mathrm{C}$ for $6 \mathrm{~h}$ to reduce the presence of soilborne pathogens and then sieved to $4 \mathrm{~mm}$. The moisture content of the sandy soil was adjusted to $10 \%$ and the loamy and clayey soils were adjusted to $20 \%$ to allow for optimal mixing. After mixing, the soil mix was packed into 15 -cm-diameter plastic pots to provide $1.7 \mathrm{~L}$ of soil volume in each pot.

The nutrient and organic matter content and $\mathrm{pH}$ for the VC used in the experiment were determined by analyzing three $20 \mathrm{~g}$ VC bulk dried samples (Brookside Laboratories Inc., New Knoxville, OH, USA). The VC had a pH of 6.1, organic matter content of $0.52 \mathrm{~g} / \mathrm{g}$, and $\mathrm{N}, \mathrm{P}$, and $\mathrm{K}$ content of $20,710,3610$, and $4580 \mathrm{mg} / \mathrm{kg}$, respectively. The levels of $\mathrm{Ca}, \mathrm{Mg}$, and $\mathrm{S}$ were $33,330,5040$, and $2540 \mathrm{mg} / \mathrm{kg}$, respectively; and the micronutrients $\mathrm{B}, \mathrm{Fe}, \mathrm{Cu}, \mathrm{Zn}, \mathrm{Mn}$, and

Table 1 Results of textural analysis of Illinois soils (Sabey et al. 2003) used for the tomato vermicompost greenhouse study

Soil separate content $(\%)$

\begin{tabular}{lrrr}
\hline Soil series $^{\mathrm{a}}$ & Sand & Silt & Clay \\
\hline Hosmer silt loam & 5.7 & 70.0 & 24.3 \\
Darwin silty clay & 7.7 & 48.0 & 44.3 \\
Sandy orthents (loamy sand) & 81.0 & 8.7 & 10.3 \\
\hline
\end{tabular}

$\overline{{ }^{a} \text { Hosmer silt loam (fine-silty, mixed, mesic Typic, Fragiudalf) and }}$ Darwin silty clay (fine, smectitic, mesic Vertic Haplaquolls) were both collected in Jackson county, Illinois, USA (Fehrenbacher et al. 1984; Herman 1979); and an inclusion of sandy orthents was collected within a Medway silty clay loam (Fine-loamy, mixed, mesic Fluvaquentic Hapludolls) in Union county, Illinois, USA (Miles 1979; Fehrenbacher et al. 1984) 
$\mathrm{Na}$ were 31, 5750, 55, 192, 690, and $1290 \mathrm{mg} / \mathrm{kg}$, respectively.

'Sun Chief' tomato seeds (Seedway Inc., Elizabethtown, PA, USA) were germinated in a greenhouse and transplanted into pots at the one-leaf stage. Plants were watered 2-3 times per week for the first month after planting and then daily after that to prevent wilting. Tomato suckers were removed and plants were pruned to two fruiting stems at 1 month after transplanting, and each tomato plant was then tied to a $0.5-0.7-\mathrm{m}$-long bamboo stake. The tomato was chosen for this study for two primary reasons: (1) it is a widely grown vegetable in both greenhouse and field production systems throughout the world, and growers of this crop have a great interest in alternative nutrient systems, and (2) it was also selected since the tomato plant is a high nutrient feeder, which would determine if VC could provide sufficient nutrient resources for a crop that requires high amounts of nitrogen and other nutrients for maximum growth and development.

Plant height $(\mathrm{cm})$, leaf and flower number per plant, leaf chlorophyll content, total leaf area per plant, and dry foliage and root weight $(\mathrm{g})$ were measured at the termination of each experiment at 2 months after transplanting. The height of each plant was measured from the soil line to the tip of the tomato main plant stem. The leaf chlorophyll content was measured using a Minolta SPAD-502 chlorophyll meter (Special Products Analysis Division, Konica Minolta Sensing Inc., Osaka, Japan) on ten randomly selected mature leaves from the midportion of tomato plants within each pot. Shoots were cut at the soil surface with all leaves removed from each plant and total leaf area $\left(\mathrm{cm}^{3}\right)$ measured with a portable leaf area meter (Model LI-3000, LI-COR, Lincoln, NE, USA). Roots were washed free of soil using tap water. Root and foliage samples were oven dried at $80^{\circ} \mathrm{C}$ for $48 \mathrm{~h}$ and weighed.

Data were subjected to analysis of variance procedures using the general linear models procedure of SAS (SAS Inst., Cary, NC, USA) appropriate for a factorial experimental design to determine the effects of soil type and $\mathrm{VC}$ rate on tomato growth response variables. Fisher's Least Significance Difference (LSD) test at $P \leq 0.05$ was used to make comparisons among soil types. Orthogonal contrasts were used to make comparisons between the various combinations of low and high VC rates, nontreated control, and standard inorganic fertilizer treatments. Furthermore, data were also analyzed using regression analysis to determine the influence of $\mathrm{VC}$ rate on tomato growth responses.

\section{Results}

No interactions $(P>0.05)$ were detected between the two greenhouse experiments with either soil type or $\mathrm{VC}$ rate, and between soil type and $\mathrm{VC}$ rate for most tomato growth responses (data not presented). Thus, tomato growth data are presented by soil type and VC rate main effects (Tables 2, 3).

\section{Soil type}

Tomatoes grown in the sandy soil had the greatest plant heights, leaf and flower numbers per plant, and leaf chlorophyll content compared to the clay and loam soils (Table 2), with the loam soil generally providing the least. Although the clay and sandy soils provided similar high dry shoot foliage weights, the clay soil produced the greatest root dry weights compared to the other soils. The three soils differed $(P \leq 0.05)$ for root-to-shoot ratios and leaf area with the loam soil having the highest, followed by the clay and sandy soils, respectively. Although total leaf area per plant was not influenced by soil type, the amount of leaf area per leaf was highest for the loam soil, followed by the clay soil, with the sand soil type providing the least.

\section{Vermicompost rate}

The low VC rates $(0.05,0.1$, and $0.2 \mathrm{~g} / \mathrm{g})$ did not improve the tomato plant height, leaf and flower numbers per plant, leaf chlorophyll content, and dry root biomass compared to that of the control $(0 \mathrm{~g} / \mathrm{g})$ (Table 3). Although no differences $(P>0.05)$ were detected between the high VC rates $(0.4$ and $0.8 \mathrm{~g} / \mathrm{g})$ and the SFT for most tomato growth responses (except leaf and flower number per plant), differences $(P \leq 0.05)$ were generally observed between the low and high $\mathrm{VC}$ rates for most growth responses (except leaf SPAD value). Tomato leaf and flower number per plant responded to $\mathrm{VC}$ applications, as differences were detected among most contrasts evaluated. However, no VC rate provided tomato leaf and flower numbers on a per plant basis that were similar to SFT. Higher leaf SPAD values were also obtained for SFT compared to either $0 \mathrm{~g} / \mathrm{g}$ control or low VC rates. Although differences were not detected $(P>0.05)$ for leaf chlorophyll content between the low and high VC rates, the low rate provided lower SPAD values compared to SFT. The highest VC rate evaluated $(0.8 \mathrm{~g} / \mathrm{g} \mathrm{VC})$ also had high leaf chlorophyll content, which was similar to SFT. Most contrasts were significant $(P \leq 0.05)$ for dry shoot and root weight, except the high $\mathrm{VC}$ rates provided tomato shoot and root biomass that was similar to SFT and the $0.0 \mathrm{~g} / \mathrm{g}$ control and low VC rates had similar dry root weight. For tomato root-to-shoot ratio, most contrasts were again significant $(P \leq 0.05)$, except the high VC rates were similar to SFT. Tomato leaf area was also influenced by $\mathrm{VC}$ rate, as differences were detected $(P \leq 0.05)$ between the $0 \mathrm{~g} / \mathrm{g}$ control with both low and high VC rates as well as SFT; the high VC rates also differed from the low VC rates for tomato leaf area. 
Table 2 Influence of soil type on 'Sunchief' tomato growth responses combined for the vermicompost rates and for two greenhouse experiments

\begin{tabular}{|c|c|c|c|c|c|c|c|c|c|}
\hline \multirow[t]{2}{*}{ Soil type ${ }^{\mathrm{A}}$} & \multirow{2}{*}{$\begin{array}{l}\text { Plant } \\
\mathrm{Ht}(\mathrm{cm})^{\mathrm{B}}\end{array}$} & \multirow{2}{*}{$\begin{array}{l}\text { Flower } \\
\text { No./plant }\end{array}$} & \multirow{2}{*}{$\begin{array}{l}\text { Leaf } \\
\text { No./plant }\end{array}$} & \multirow{2}{*}{$\begin{array}{l}\text { Leaf SPAD } \\
\text { Value }^{\mathrm{C}}\end{array}$} & \multicolumn{2}{|c|}{ Dry Wt $(g)^{\mathrm{D}}$} & \multirow{2}{*}{$\begin{array}{l}\text { Root-to-shoot } \\
\text { Ratio }^{\mathrm{E}}\end{array}$} & \multicolumn{2}{|c|}{ Leaf area $\left(\mathrm{cm}^{3}\right)^{\mathrm{F}}$} \\
\hline & & & & & Shoot & Root & & Leaf & Total \\
\hline Clay & $86.0 \mathrm{~b}$ & $10.1 \mathrm{~b}$ & $6.7 \mathrm{~b}$ & $40.4 \mathrm{~b}$ & $20.6 \mathrm{a}$ & $13.9 \mathrm{a}$ & $0.67 \mathrm{~b}$ & $36.0 \mathrm{~b}$ & $241.3 \mathrm{a}$ \\
\hline Loam & $80.4 \mathrm{c}$ & $9.1 \mathrm{c}$ & $4.3 c$ & $40.0 \mathrm{~b}$ & $15.5 b$ & $11.6 \mathrm{~b}$ & $0.75 \mathrm{a}$ & $51.4 \mathrm{a}$ & $221.2 \mathrm{a}$ \\
\hline Sand & $90.7 \mathrm{a}$ & $11.2 \mathrm{a}$ & $8.6 a$ & $43.5 \mathrm{a}$ & $21.7 \mathrm{a}$ & $11.7 \mathrm{~b}$ & $0.54 \mathrm{c}$ & $26.2 \mathrm{c}$ & $225.0 \mathrm{a}$ \\
\hline
\end{tabular}

All measurements were taken at the termination of the experiments at 2 months after transplanting. Tomato growth response means followed by the same letter within a column do not differ significantly at $P \leq 0.05$

A Clay was Darwin silty clay (Fine, smectitic, mesic Vertic Haplaquolls), loam was a Hosmer silt loam (Fine-silty, mixed, mesic Typic, Fragiudalf), and sand came from an inclusion of sandy orthents within a Medway silty clay loam (Fine-loamy, mixed, mesic Fluvaquentic Hapludolls)

B Plant heights were measured for each plant from the soil line to the tip of the tomato main plant stem

${ }^{\mathrm{C}}$ Leaf SPAD values were measured using a Minolta SPAD-502 chlorophyll meter (Special Products Analysis Division, Konica Minolta Sensing Inc., Osaka, Japan) on 10 randomly collected leaves from the mid-portion of plants in each plot

D Roots and foliage samples were oven dried at $80{ }^{\circ} \mathrm{C}$ for $48 \mathrm{~h}$

${ }^{\mathrm{E}}$ Root-to-shoot ratio is the root weight divided by shoot weight

F Leaf area was measured using a portable leaf area meter (Model LI-3000, LI-COR, Lincoln, NE, USA)

Tomato plant growth responses generally increased with the increasing VC application rates (Table 3). Tomato plant height increased in a quadratic manner with the increasing $\mathrm{VC}$ rate. Approximately $0.66 \mathrm{~g} / \mathrm{g} \mathrm{VC}$ provided the optimal rate to maximize tomato plant height $[y=78.42+0.39$ (VC rate) -0.003 (VC rate $\left.)^{2}, R^{2}=0.95, P=0.0097\right]$. Quadratic relationships also explained the increase in leaf and flower number per plant with increasing $\mathrm{VC}$ rate, although there was only a 2.6 leaf and 4.0 flower increase per plant from the $0 \mathrm{~g} / \mathrm{g}$ control to the highest $\mathrm{VC}$ rate $(0.8 \mathrm{~g} / \mathrm{g})$. The optimum VC application rates to achieve maximum leaf $[y=8.92+0.04$ (VC rate) $\left.-0.0002(\mathrm{VC} \text { rate })^{2}, R^{2}=0.96, P=0.0077\right]$ and flower numbers $[y=3.77+0.15$ (VC rate) -0.001 (VC rate $)^{2}, R^{2}=0.95, P=0.0103$ ] per plant were about 0.80 and $0.59 \mathrm{~g} / \mathrm{g}$, respectively. Tomato leaf chlorophyll content increased in a linear manner with the increasing $\mathrm{VC}$ application rate $\left[y=39.67+0.05\right.$ (VC rate), $\left.R^{2}=0.70, P=0.0381\right]$. Tomato dry shoot and root biomass increased in a quadratic $\left[y=13.67+0.24 \quad(\mathrm{VC}\right.$ rate $)-0.0015 \quad(\mathrm{VC} \text { rate })^{2}$, $\left.R^{2}=0.99, P=0.0005\right]$ and linear $[y=11.74+0.02(\mathrm{VC}$ rate), $\left.R^{2}=0.64, P=0.0576\right]$ manner, respectively, with the increasing VC application rate; and approximately, 0.70 and $0.80 \mathrm{~g} / \mathrm{g}$ VC provided the highest tomato shoot and root biomass, respectively, which was similar to the SFT in both cases. The decrease in the root-to-shoot ratio with the increasing VC rate was best described by a quadratic model $\left[y=0.82+0.007\right.$ (VC rate) $-0.00005 \quad(\mathrm{VC} \text { rate })^{2}$, $\left.R^{2}=0.97, P=0.0064\right]$, with about $0.60 \mathrm{~g} / \mathrm{g}$ VC rate providing the lowest root-to-shoot ratio. Lastly, total tomato leaf area increased in a quadratic manner as VC application rate increased $\left[y=181.74+2.66\right.$ (VC rate) $-0.025(\mathrm{VC} \text { rate })^{2}$, $\left.R^{2}=0.87, P=0.0459\right]$, with leaf area optimized at the $0.53 \mathrm{~g} / \mathrm{g}$ VC rate.

\section{Discussion}

The use of VC as a fertilizer source for tomato growth provided no advantage compared to a standard inorganic fertilizer, although the higher amounts of VC applied improved tomato growth over the untreated control. However, other benefits provided by VC such as soil structure improvement and increase in soil microbial populations (Edwards and Burrows 1988; Canellas et al. 2002) compared to petroleum-based synthetic fertilizers should be considered and may be more ideal for certain situations. Results from this study indicated: (1) VC enhanced tomato growth particularly for the sandy soil type; (2) VC application rate affected tomato plant growth response, and soils with higher amounts of VC (0.4 and $0.8 \mathrm{~g} / \mathrm{g})$ generally resulted in taller tomato plants with greater leaf and root biomass, more leaves and flowers, higher chlorophyll content and increased leaf area than the non-treated control or low VC rates; and (3) the soil VC application rate to achieve optimal tomato growth parameter responses was between 0.5 and $0.6 \mathrm{~g} / \mathrm{g}$.

Although VC additions will improve soil structure primarily through increases in organic matter, tomato growth differed among soil types that were amended with VC. The sandy soil with VC amendments generally produced greater tomato plant heights, leaf and flower numbers per plant, and leaf chlorophyll content compared to the clay and loam soils, with the loam soil generally providing the least (Table 2). The influence of soil type on the tomato growth parameters was most likely due to VC improvements in soil structure allowing for greater water retention and aeration, especially in the sandy soil. However, in this experiment, the loamy and clayey soils appeared to become 
Table 3 Influence of vermicompost (VC) rate on 'Sunchief' tomato plant growth responses combined over the three soil types evaluated

\begin{tabular}{|c|c|c|c|c|c|c|c|c|}
\hline \multirow{2}{*}{$\begin{array}{l}\text { Vermicompost } \\
\text { Rate }(\mathrm{g} / \mathrm{g})^{\mathrm{a}}\end{array}$} & \multirow{2}{*}{$\begin{array}{l}\text { Plant } \\
\mathrm{Ht}(\mathrm{cm})^{\mathrm{b}}\end{array}$} & \multirow{2}{*}{$\begin{array}{l}\text { Leaf } \\
\text { No./plant }\end{array}$} & \multirow{2}{*}{$\begin{array}{l}\text { Flower } \\
\text { No./plant }\end{array}$} & \multirow{2}{*}{$\begin{array}{l}\text { Leaf SPAD } \\
\text { Value }^{c}\end{array}$} & \multicolumn{2}{|c|}{ Dry Wt $(\mathrm{g})^{\mathrm{d}}$} & \multirow{2}{*}{$\begin{array}{l}\text { Root-to-shoot } \\
\text { Ratio }^{\mathrm{e}}\end{array}$} & \multirow[t]{2}{*}{ Leaf $\operatorname{area}^{\mathrm{f}}\left(\mathrm{cm}^{3}\right)$} \\
\hline & & & & & Shoot & Root & & \\
\hline 0.0 & 77.9 & 8.8 & 3.8 & 38.8 & 14.1 & 11.9 & 0.84 & 168.7 \\
\hline \multicolumn{9}{|l|}{ Low } \\
\hline 0.05 & 80.1 & 9.0 & 4.1 & 39.1 & 14.4 & 11.2 & 0.77 & 201.4 \\
\hline 0.1 & 82.0 & 9.7 & 5.3 & 41.9 & 16.0 & 11.7 & 0.73 & 211.5 \\
\hline 0.2 & 87.0 & 9.7 & 6.9 & 41.0 & 17.8 & 12.9 & 0.72 & 234.6 \\
\hline \multicolumn{9}{|l|}{ High } \\
\hline 0.4 & 88.0 & 10.3 & 7.4 & 41.3 & 21.1 & 12.8 & 0.61 & 237.0 \\
\hline 0.8 & 91.1 & 11.4 & 7.8 & 43.5 & 23.2 & 13.2 & 0.57 & 237.4 \\
\hline SFT & 93.9 & 12.2 & 10.5 & 43.7 & 24.6 & 13.5 & 0.55 & 232.8 \\
\hline \multicolumn{9}{|l|}{ Contrasts $^{\mathrm{g}}$} \\
\hline None vs. low & NS & NS & NS & NS & $* *$ & NS & $* *$ & $* *$ \\
\hline None vs. high & $*$ & $* * *$ & $* * *$ & $*$ & $* * *$ & $* *$ & $* * *$ & $* * *$ \\
\hline None vs. SFT & $* *$ & $* * *$ & $* * *$ & $* *$ & $* * *$ & $*$ & $* * *$ & $* * *$ \\
\hline Low vs. high & $*$ & $* * *$ & $* *$ & NS & $* * *$ & $*$ & $* * *$ & $* *$ \\
\hline Low vs. SFT & $* *$ & $* * *$ & $* * *$ & $*$ & $* * *$ & $* *$ & $* * *$ & NS \\
\hline High vs. SFT & NS & $* *$ & $* *$ & NS & NS & NS & NS & NS \\
\hline \multicolumn{9}{|c|}{ Significance of VC rate trend ${ }^{\mathrm{h}}$} \\
\hline Linear & $* *$ & $* *$ & $*$ & $*$ & $* *$ & $*$ & $* *$ & NS \\
\hline Quadratic & $* *$ & $* *$ & $* *$ & NS & $* *$ & NS & $* *$ & $*$ \\
\hline
\end{tabular}

All measurements were taken at the termination of the experiments at 2 months after transplanting. The three soil types evaluated were clay (silty clay), loam (silt loam), and sand (silty clay loam)

NS, $*, * * * * *$ Nonsignificant or significant at $P \leq 0.05, P \leq 0.01$, or $P \leq 0.0001$, respectively

${ }^{a}$ SFT is the standard fertilizer treatment and was an inorganic 12-12-12 (N-P-K) complete fertilizer applied at $2 \mathrm{~g}$ per $1.7 \mathrm{~L}$ pot

${ }^{b}$ Plant heights were measured for each plant from the soil line to the tip of the tomato main plant stem

c The leaf SPAD value was measured using a Minolta SPAD-502 chlorophyll meter (Special Products Analysis Division, Konica Minolta Sensing Inc., Osaka, Japan) on 10 randomly collected leaves from the mid-portion of each plant

${ }^{d}$ Root and foliage samples were oven dried at $80{ }^{\circ} \mathrm{C}$, with dry weights taken after $48 \mathrm{~h}$

e Root-to-shoot ratio was root dry weight divided by shoot dry weight

${ }^{\mathrm{f}}$ Leaf area was measured using a portable leaf area meter (Model LI-3000, LI-COR, Lincoln, NE, USA)

$\mathrm{g}$ Low is the combination of $0.05,0.1$ and $0.2 \mathrm{~g} / \mathrm{g}$ vermicompost rates and High is the combination of 0.4 and $0.8 \mathrm{~g} / \mathrm{g}$ vermicompost rates, while None $=0 \mathrm{~g} / \mathrm{g}$ vermicompost

${ }^{\mathrm{h}}$ SFT is used only in contrast comparisons and is not included in the calculation of linear and quadratic models

more compacted over the duration of the experiment, which would definitely have an effect on plant growth (Brady and Weil 2008).

Vermicompost application rate affected all tomato plant growth characteristics in this study and provided further evidence of VC as a suitable alternative-type fertilizer for tomato which is comparable to other studies including Arancon et al. (2003), Gutiérrez-Miceli et al. (2007), and Roberts et al. (2007). This study indicated that addition of 0.5 to $0.6 \mathrm{~g} / \mathrm{g} \mathrm{VC}$ to soils provided optimal tomato plant growth, since this rate provided tomato growth results similar to the standard inorganic fertility program and application rates $>0.6 \mathrm{~g} / \mathrm{g}$ tended to result in excessive amounts of shoot growth as well as low root-to-shoot ratios (Table 3). Arancon et al. (2003) indicated that the improvements in tomato plant growth due to $\mathrm{VC}$ application may be due to increases in microbial populations in soils provided by these materials. However, other research has indicated that increased plant growth and yields with VC may be due to the production of plant growth regulators by microorganisms or to the effects of humates (Canellas et al. 2002). Regardless, the addition of organic composts or VC to soil tends to improve soil structure, increase microbial population and activity, and increase water retention (Edwards and Burrows 1988; Edwards 2004). Therefore, the use of organic composts, such as VC, can provide various benefits to soils while, at the same time, providing a fertility source for selected vegetable crops.

Vermicomposts can be used as a source of nutrients for vegetable crops, as well as increasing soil organic matter, 
improving soil structure, and providing increases in soil microbial populations which all have beneficial effects on plant growth and development (Arancon et al. 2003, 2004a; Gutiérrez-Miceli et al. 2007). Furthermore, the recycling of organic wastes into composts for use as alternative fertilizers can reduce the need and dependence on synthetic, inorganic fertilizers by both small- and large-scale vegetable producers. Many amateur home gardeners as well as commercial vegetable growers are interested in using environment-friendly alternative type fertilizers, such as VC, that can supply sufficient amounts of nutrients for crop growth and development while at the same time improving the physical properties of soils. Thus, there is great potential to increase the use of these fertilizers by both commercial vegetable growers and home vegetable gardeners.

\section{Conclusions}

This research provided further evidence for $\mathrm{VC}$ as a suitable alternative fertilizer for tomato, with approximately $0.5-0.6 \mathrm{~g} / \mathrm{g} \mathrm{VC}$ added to soil resulting in optimal tomato plant growth. Moreover, this rate provided tomato growth similar to the standard inorganic fertility program. The sandy soil with VC amendments generally increased tomato plant growth parameters the most compared to the clay and loam soils, with the loam soil generally providing the least.

Acknowledgments The investigators would like to express their sincere thanks to Illinois Dept of Agriculture Sustainable 2000 Grant Program and Illinois Department of Commerce and Economic Opportunity for funding this research. Special thanks are also extended to Mr. Chad Hurley at New Horizon Organics Inc. in Jerseyville, IL and all personnel at the Horticulture Research Center, SIUC for their assistance in conducting this research. The tomato seed used in this study was generously provided by Rupp Seeds Inc., Wauseon, OH.

Conflict of interest The authors declare that they have no conflict of interest.

Author contribution This paper is based on a thesis submitted by Mr. Marc Zucco, who is a former graduate student at the Department of Plant, Soil, and Agricultural Systems at SIUC, Carbondale, Illinois, USA. He is now a soil scientist with the Natural Resources Conservation Service (NRCS) in Grayling, Michigan, USA. Dr. Alan Walters is Professor of Vegetable Science and Director of the Southern Illinois University Sustainable Farming Center. This center includes a vermicomposting facility in which University food wastes are recycled and used as a fertilizer source and soil enhancer for the Organic Vegetable Farm located next to the facility. Dr. Chong is an Emeritus Professor of Soil Science, who was involved in vermicompost research prior to his retirement and is now involved in various international activities, especially in China. Dr. Brian Klubek is Emeritus Professor of Soil Microbiology and former Chair of the Dept of Plant, Soil, and Agricultural Systems at Southern Illinois University, Carbondale, Illinois, USA. Dr. Joseph Masabni is an Assistant Professor and Extension Vegetable Specialist at Texas A\&M University and collaborated with the authors in writing this manuscript.

Open Access This article is distributed under the terms of the Creative Commons Attribution 4.0 International License (http:// creativecommons.org/licenses/by/4.0/), which permits unrestricted use, distribution, and reproduction in any medium, provided you give appropriate credit to the original author(s) and the source, provide a link to the Creative Commons license, and indicate if changes were made.

\section{References}

Agnieszka R, Kacprzak M, Vandenbulcke F, Paytycz B (2013) Soil amendment with municipal sewage sludge affects the immune system of earthworms Dendrobaena veneta. Appl Soil Ecol 64:237-244

Alsina I, Dubova L, Steinberga V, Gmizo G (2013) The effect of vermicompost on the growth of radish. Acta Horticulturae 1013:359-365

Arancon NQ, Edwards CA, Bierman P, Metzger JD, Lee S, Welch C (2003) Effects of vermicomposts on growth and marketable fruits of field-grown tomatoes, peppers and strawberries. Pedobiolagia 47:731-735

Arancon NQ, Edwards CA, Atiyeh R, Metzer JD (2004a) Effects of vermicomposts produced from food waste on the growth and yields of greenhouse peppers. Bioresource Technol 93:139-144

Arancon NQ, Edwards CA, Bierman P, Welch C, Metzger JD (2004b) Influences of vermicomposts on field strawberries: 1. Effects on growth and yields. Bioresour Technol 93:145-153

Atiyeh RM, Dominguez J, Subler S, Edwards CA (2000) Changes in biochemical properties of cow manure during processing by earthworms (Eisenia andrei) and the effects on seedling growth. Pedobiologia 44:709-724

Atiyeh RM, Lee S, Edwards CA, Arancon NQ, Metzger JD (2002) The influence of humic acids derived from earthworm-processed organic wastes on plant growth. Bioresour Technol 84:7-14

Brady NC, Weil RR (2008) The nature and properties of soils, 14th edn. Pearson/Prentice Hall, Upper Saddle River

Canellas LP, Olivares FL, Okorokova-Façanha AL, Façanha AR (2002) Humic acids isolated from earthworm compost enhance root elongation, lateral root emergence, and plasma $\mathrm{H}+$-ATPase activity in maize roots. Plant Physiol 130:1951-1957

Edwards CA (2004) Earthworm ecology, 2nd edn. CRC Press, Boca Raton

Edwards CA, Burrows I (1988) The potential of earthworm composts as plant growth media. In: Edwards CA, Neuhauser EF (eds) Earthworms in Environmental and Waste Management. SPB Academic Publ., The Hague, pp 211-220

Fehrenbacher JB, Alexander JD, Jensen IJ, Darmody RG, Pope RA, Flock MA, Vass EE, Scott JW, Andrews WF, Bushue JJ (1984) Soils of Illinois. Bul 778. Illinois Agr Expt Stat and USDA Soil Conserv Serv. Champaign-Urbana, IL

Gopalakrishnan S, Humayun P, Vadlamudi S, Vijayabharathi R, Bhimineni RK, Rupela O (2012) Plant growth-promoting traits of streptomyces with biocontrol potential isolated from herbal vermicompost. Biocontrol Sci Tech 22(10):1199-1210

Gutiérrez-Miceli FA, Santiago-Borraz J, Molina JAM, Nafate CC, Abud-Archila M, Llaven MAO, Rincón-Rosales R, Dendooven L (2007) Vermicompost as a soil supplement to improve growth, yield and fruit quality of tomato (Lycopersicon esculentum). Bioresour Tech 98:2781-2786

Herman RJ (1979) Soil survey of Jackson county, IL. Illinois Agr Expt Stat Soil Rpt 106. Champaign-Urbana, IL 
Miles CC (1979) Soil survey of Union county, IL. Illinois Agr Expt Stat Soil Rpt 110. Champaign-Urbana, IL

Pandya U, Maheshwari DK, Saraf M (2014) Assessment of ecological diversity of rhizobacterial communities in vermicompost and analysis of their potential to improve plant growth. Biologia 69(8):968-976

Pascal J, Plumere T, Thu TD, Rumpel C, Duc TT, Orange D (2010) The rehabilitation of tropical soils using compost and vermicompost is affected by the presence of endogenic earthworms. Appl Soil Ecol 46(1):125-133

Pascual JA, Garcia C, Hernandez T, Ayuso M (1997) Changes in the microbial activity of an arid soil amended with urban organic wastes. Biol Fertil Soils 24:429-434
Roberts P, Jones DL, Edward-Jones G (2007) Yield and vitamin C content of tomatoes grown in vermicompost wastes. J Sci Food Agric 87:1957-1963

Sabey BR, Klubek BP, Chong S-K, Varsa EC (2003) Introductory experimental soil science, 2nd edn. Stipes Publ, Champaign

Subler S, Edwards CA, Metzger JD (1998) Comparing vermicomposts and composts. Biocycle 39:63-66

Yadav A, Garg VK (2011) Recycling of organic wastes by employing Eisenia fetida. Bioresource Tech 102(3):2874-2880 